\title{
The risk of community-acquired pneumonia in children using gastric acid suppressants
}

\author{
Citation for published version (APA):
}

van der Sande, L. J. T. M., Jöbsis, Q., Bannier, M. A. G. E., van de Garde, E. M. W., Coremans, J. J. M., de Vries, F., Dompeling, E., \& Driessen, J. H. M. (2021). The risk of community-acquired pneumonia in children using gastric acid suppressants. European Respiratory Journal, 58(4), [2003229]. https://doi.org/10.1183/13993003.03229-2020

Document status and date:

Published: 01/10/2021

DOI:

10.1183/13993003.03229-2020

Document Version:

Publisher's PDF, also known as Version of record

Document license:
Taverne

\section{Please check the document version of this publication:}

- A submitted manuscript is the version of the article upon submission and before peer-review. There can be important differences between the submitted version and the official published version of record.

People interested in the research are advised to contact the author for the final version of the publication, or visit the DOI to the publisher's website.

- The final author version and the galley proof are versions of the publication after peer review.

- The final published version features the final layout of the paper including the volume, issue and page numbers.

Link to publication

\footnotetext{
General rights rights.

- You may freely distribute the URL identifying the publication in the public portal. please follow below link for the End User Agreement:

www.umlib.nl/taverne-license

Take down policy

If you believe that this document breaches copyright please contact us at:

repository@maastrichtuniversity.nl

providing details and we will investigate your claim.
}

Copyright and moral rights for the publications made accessible in the public portal are retained by the authors and/or other copyright owners and it is a condition of accessing publications that users recognise and abide by the legal requirements associated with these

- Users may download and print one copy of any publication from the public portal for the purpose of private study or research.

- You may not further distribute the material or use it for any profit-making activity or commercial gain

If the publication is distributed under the terms of Article $25 \mathrm{fa}$ of the Dutch Copyright Act, indicated by the "Taverne" license above, 


\title{
The risk of community-acquired pneumonia in children using gastric acid suppressants
}

\author{
Linda J.T.M. van der Sande $\mathbb{(}^{1}$, Quirijn Jöbsis ${ }^{1}$, Michiel A.G.E. Bannier ${ }^{1}$, Ewoudt M.W. van de Garde $\mathbb{B}^{2}$, \\ Jan J.M. Coremans ${ }^{3}$, Frank de Vries $\mathbb{1}^{2,3,4}$, Edward Dompeling ${ }^{1,5}$ and Johanna H.M. Driessen ${ }^{2,3,4,5}$
}

${ }^{1}$ Dept of Pediatric Pulmonology, School for Public Health and Primary Care (CAPHRI), Maastricht University Medical Center (MUMC+), Maastricht, The Netherlands. ${ }^{2}$ Dept of Pharmaceutical Sciences, Division of Pharmacoepidemiology and Clinical Pharmacology, University of Utrecht, Utrecht, The Netherlands. ${ }^{3}$ Dept of Clinical Pharmacy and Toxicology, Maastricht University Medical Center (MUMC+), Maastricht, The Netherlands. ${ }^{4}$ School for Nutrition and Translational Research in Metabolism (NUTRIM), Maastricht University, Maastricht, The Netherlands. ${ }^{5}$ E. Dompeling and J.H.M. Driessen are joint senior authors.

Corresponding author: Linda J.T.M. van der Sande (linda.vander.sande@mumc.nl)

Copyright (C)The authors 2021. For reproduction rights and permissions contact permissions@ersnet.org

Received: 21 Aug 2020 Accepted: 21 Feb 2021
Shareable abstract (@ERSpublications)

In this large cohort study, the use of acid suppressants in children, both PPIs and H2RAs, was associated with a doubled risk of CAP. This risk increased with chronic use and respiratory disease, and remained increased after discontinuation of therapy. https://bit.ly/3suT7s3

Cite this article as: van der Sande LJTM, Jöbsis Q, Bannier MAGE, et al. The risk of communityacquired pneumonia in children using gastric acid suppressants. Eur Respir J 2021; 58: 2003229 [DOI: 10.1183/13993003.03229-2020].

\section{Abstract}

Background With the increased use of acid suppressants, significant potential complications such as community-acquired pneumonia (CAP) are becoming more apparent. Paradoxically, in spite of an increased focus on potential complications, there is an increased use of acid suppressants in children and a lack of data specifically targeting the association between acid suppressants and CAP. Our main objective was to evaluate the risk of CAP in children using acid suppressants (proton pump inhibitors (PPIs) and/or histamine-2 receptor antagonists (H2RAs)).

Methods We performed a cohort study using data from the UK Clinical Practice Research Datalink. All patients aged 1 month to 18 years with a prescription of acid suppressants were included and matched to up to four unexposed children. Time-varying Cox proportional hazards models were used to estimate the risk of CAP. The cohort consisted of 84868 exposed and 325329 unexposed children.

Results Current use of PPIs and H2RAs was associated with an increased risk of CAP (adjusted hazard ratio 2.05 (95\% CI 1.90-2.22) and 1.80 (95\% CI 1.67-1.94), respectively). The risk was even greater in patients with respiratory disease. Long-term use ( $\geqslant 211$ days) of PPIs and H2RAs led to a significantly greater risk of CAP compared with short-term use ( $<31$ days). After cessation of therapy, the risk remained increased for the following 7 months.

Conclusion The use of acid suppressants in children was associated with a doubled risk of CAP. This risk increased with chronic use and respiratory disease, and remained increased after discontinuation of therapy.

\section{Introduction}

Acid suppressants are often prescribed in the management of symptoms of gastro-oesophageal reflux (disease) in both children and adults. Over the past decades, the consumption of acid suppressants such as proton pump inhibitors (PPIs) and histamine-2 receptor antagonists (HR2As) has increased considerably. In children, a 2-8-fold increase in prescriptions for acid suppressants was observed [1-4], in spite of the increased awareness of potential adverse effects and guideline recommendations to exercise caution when prescribing for children [5]. Over the course of time, potential complications in adults became apparent: various systematic reviews and meta-analyses described an association between acid suppressants and community-acquired pneumonia (CAP) [6-9]. Although there are a number of adult studies assessing the proposed association, there are hardly any studies in children and those that are available show conflicting results. CANani et al. [10] performed a prospective cohort study in 186 children aged 4-36 months (47 ranitidine users, 44 omeprazole users and 95 nonusers), demonstrating that the use of acid suppressants 
was associated with a 6-fold increased risk of CAP. BLANK et al. [11] conducted a nested case-control study in 21911 infants, comparing the risk of CAP resulting in hospitalisation or death in current users and past users of PPIs. Their results did not show an increased risk of CAP in current users compared with past users. However, never users were not included in this study.

Given the widespread use of acid suppressants, the significance of CAP as a serious childhood infection [12], and the paucity of data regarding the association between acid suppressants and CAP in children, there is an urgent need to assess the potential impact of acid suppressants on the risk of CAP in children. The specific objectives of this study were: 1) to evaluate the risk of developing CAP in children using PPIs and/or H2RAs, 2) to assess the influence of a chronic respiratory disease (e.g. asthma, bronchopulmonary dysplasia and cystic fibrosis), and 3) to compare the risk between current, recent, past and never users of acid suppressants, and to assess the effect of prolonged use and cessation of therapy.

\section{Methods}

\section{Study design}

We performed a cohort study using the UK Clinical Practice Research Datalink (CPRD) GOLD, a large primary care database of anonymised medical records of 740 primary care practices. Since 1987, the CPRD has recorded data such as patient demographics, medical history, laboratory test results, medical diagnosis and prescription details [13]. The CPRD has been extensively used and validated for pharmacoepidemiological and epidemiological research, and has been shown to be representative for populations outside the UK [13, 14]. The protocol for this study was approved by the Independent Scientific Advisory Committee for Medicines and Healthcare products Regulatory Agency (MHRA) Database research (protocol 18_107).

\section{Study population}

The study cohort consisted of children aged 1 month to 18 years with at least one prescription for either a PPI or H2RA (exposed patients) during the period of data collection from 1 January 1995 to 31 December 2017. The first prescription of an acid suppressant defined the start of follow-up (index date). Each exposed patient was matched by year of birth, sex and practice to up to four children without a prescription for an acid suppressant (unexposed patients), using the incidence density sampling technique, and they were assigned the index date of their matched exposed patient. From both the exposed and unexposed population, children with a history of active tuberculosis, malignancies or use of tuberculosis medication prior to the index date were excluded. Patients using immunosuppressant medication 6 months prior to the index date and patients with a history of pneumonia 3 months prior to the index date were also excluded. Every patient was followed from his/her index date up to the end of data collection, until he/she turned 18 years old, until he/she died or when the outcome of interest occurred, whichever came first.

The exposure of interest was the prescription of a PPI and/or H2RA. The follow-up time was stratified into periods of 30 days. Before the start of each period, exposure to either PPIs or H2RAs was determined, dividing person-time into "current use”, "recent use”, "past use”, “distant past use” and "never use”. The distribution of person-time in the different groups was based on the time that had passed since the most recent prescription: 1-30 days was defined as "current use", 31-60 days as "recent use", 61-210 days as "past use" and $\geqslant 211$ days as "distant past use". As a result of this classification, patients were able to move between groups during follow-up. Clearly, "never users” had no history of prescription of a PPI or H2RA.

Each current use interval was further stratified by continuous duration of use. To determine continuous duration of use, the prescribed quantity and the written dosage instructions were used to estimate the duration of each PPI/H2RA prescription. Continuous duration was then defined as the time from the first continuous prescription until the start of an interval, allowing a gap of 60 days between the estimated end date of a prescription and the start of the next prescription.

\section{Outcome of interest}

The primary outcome of interest was the occurrence of CAP in the full CPRD cohort (Read codes available upon request). CAP was defined according to the British Thoracic Society definition: persistent or repetitive fever together with chest recessions and a raised respiratory rate [15]. We selected Read codes based on the description of this clinical syndrome. We reviewed the literature to identify risk factors for the outcomes of interest. These risk factors were used as potential confounders (for the estimation of relative risks). Potential confounders were assessed in a time-dependent manner, with the exception of sex, and were collected at the start of each time interval. All variables were treated as categorical variables (with the exception of age) and we used dummy indicator variables to account for missing data. Potential confounders included age, sex, a history of pneumonia, a history of gastro-oesophageal reflux, chronic 
lung diseases (asthma, bronchopulmonary dysplasia and cystic fibrosis) and (severe) psychomotor disability.

\section{Statistical analysis}

Cox proportional hazard models (PHREG procedure in SAS version 9.4; SAS Institute, Cary, NC, USA) were used to estimate the hazard ratios (HRs) for CAP in acid suppressant users compared with never users. We tested for statistical differences between PPI use or H2RA use, applying the Wald statistic. PPI and H2RA use was stratified by time since the most recent prescription. Hazard ratios were adjusted for age, sex and potential confounders that showed a $>5 \%$ change in the $\beta$-coefficient of an age/sex-adjusted analysis or when consensus about inclusion existed within the team of researchers supported by clinical evidence from the literature.

\section{Results}

\section{Patient characteristics}

447759 patients aged 1 month to 18 years were identified in the CPRD database, consisting of 90858 children exposed to a PPI and/or H2RA and 356901 children unexposed to a PPI and/or H2RA at baseline. Subsequently, we excluded 14538 unique patients (5985 exposed children and 8553 unexposed children) based on the following exclusion criteria: history of pneumonia 3 months prior to the index date $(n=4100)$, active tuberculosis or use of medication for tuberculosis $(n=3921)$, use of immunosuppressant drugs ( $n=962)$ and/or malignancy $(n=6352)$. Matched cases and controls of excluded patients were excluded as well when there was no longer a matched set of a case and at least one control $(\mathrm{n}=23023)$. Therefore, our study cohort consisted of a total of 410197 children, of whom 84868 were exposed and 325329 were unexposed at baseline.

The baseline characteristics of the cohorts are described in table 1. The mean duration of follow-up, mean age, sex distribution and age distribution at cohort entry were similar in both cohorts. As expected, in comparison with unexposed patients, the patients in the exposed cohort were more likely to have a diagnosis of gastro-oesophageal reflux 1 year prior to the index date.

\section{Risk of developing CAP}

An increased risk of developing CAP was found in all types of users of PPIs and H2RAs (current, recent, past and distant past users) compared with never users (tables 2 and 3).

Current use of PPIs was associated with a 2-fold increased risk of developing CAP compared with never use (adjusted HR (aHR) 2.05 (95\% CI 1.90-2.22)). Prolonged use of PPIs for $>30$ days was also associated with a higher risk of CAP, particularly in long-term users ( $\geqslant 211$ days; aHR 2.34 (95\% CI 2.062.67)). Moreover, the risk of CAP in continued current use for $\geqslant 211$ days was significantly higher than the risk in continued current use for <31 days (aHR 2.53 (95\% CI 2.22-2.88) versus 2.05 (95\% CI 1.78-2.32); $\mathrm{p}=0.028$ ). After cessation of PPI treatment, the risk of CAP decreased slowly over time; in the first 7 months after discontinuation, the aHR was 1.72 (95\% CI 1.53-1.94) for recent use, a 1.8-fold increased

TABLE 1 Baseline characteristics of the acid suppressant users and controls (nonusers) at cohort entry in the study

\begin{tabular}{|c|c|c|}
\hline & Users & Nonusers \\
\hline Subjects & 84868 & 325329 \\
\hline Follow-up time years & $3.7 \pm 3.1$ & $3.6 \pm 3.1$ \\
\hline Female & $45212(53.3)$ & $173533(53.3)$ \\
\hline Age at index date years & $9.0 \pm 6.8$ & $8.9 \pm 6.7$ \\
\hline \multicolumn{3}{|l|}{ History of disease } \\
\hline Pneumonia` & $13026(15.3)$ & $39794(12.2)$ \\
\hline Gastro-oesophageal reflux ${ }^{+}$ & $18258(21.5)$ & $4032(1.2)$ \\
\hline Asthma & $11058(13.0)$ & $32012(9.8)$ \\
\hline Bronchopulmonary dysplasia & $86(0.1)$ & $44(0.0)$ \\
\hline Cystic fibrosis & $346(0.4)$ & $56(0.0)$ \\
\hline Psychomotor disability & $505(0.6)$ & $352(0.1)$ \\
\hline
\end{tabular}


TABLE 2 Use of proton pump inhibitors (PPIs) and risk of community-acquired pneumonia (CAP)

\begin{tabular}{|c|c|c|c|c|}
\hline Exposure & $\begin{array}{c}\text { CAP } \\
\text { events } n\end{array}$ & $\begin{array}{l}\text { Incidence rate per } \\
1000 \text { person-years }\end{array}$ & $\begin{array}{c}\text { Age/sex-adjusted } \\
\text { HR }(95 \% \mathrm{CI})\end{array}$ & $\begin{array}{l}\text { Fully adjusted } \\
\mathrm{HR}^{\#}(95 \% \mathrm{Cl})\end{array}$ \\
\hline Never PPI or H2RA & 21471 & 19.1 & Reference & Reference \\
\hline \multicolumn{5}{|l|}{ PPI use by time since last prescription } \\
\hline Current: $1-30$ days & 739 & 68.4 & $2.66(2.47-2.86)$ & $2.05(1.90-2.22)$ \\
\hline Recent: $31-60$ days & 288 & 45.2 & $2.13(1.89-2.39)$ & $1.72(1.53-1.94)$ \\
\hline Past: $61-210$ days & 729 & 36.9 & $2.12(1.97-2.28)$ & $1.79(1.66-1.93)$ \\
\hline Distant past: $\geqslant 211$ days & 1588 & 19.8 & $1.39(1.32-1.46)$ & $1.29(1.23-1.36)$ \\
\hline \multicolumn{5}{|l|}{ Current PPI use by duration of use } \\
\hline $1-30$ days & 186 & 41.8 & $2.29(1.99-2.65)$ & $1.89(1.63-2.18)$ \\
\hline $31-60$ days & 75 & 80.1 & $2.22(1.77-2.79)$ & $1.81(1.44-2.27)$ \\
\hline $61-210$ days & 241 & 95.1 & $2.62(2.30-2.97)$ & $2.04(1.79-2.32)$ \\
\hline$\geqslant 211$ days & 237 & 82.0 & $3.32(2.92-3.77)$ & $2.34(2.06-2.67)$ \\
\hline Current use of both PPI and H2RA & 73 & 111.1 & $3.47(2.76-4.36)$ & $2.52(2.00-3.18)$ \\
\hline
\end{tabular}

H2RA: histamine-2 receptor antagonist; HR: hazard ratio. ": adjusted for age, sex, history of pneumonia, gastro-oesophageal reflux 1 year before, asthma, bronchopulmonary dysplasia and cystic fibrosis. All analyses are adjusted for use of H2RAs.

risk was found for past use (aHR 1.79 (95\% CI 1.66-1.93)) and a 1.3-fold increased risk was found for distant past use (aHR 1.29 (95\% CI 1.23-1.36)).

Regarding the use of H2RAs, comparable results were found: current use of H2RAs was associated with a 1.8-fold increased risk of developing CAP compared with never use (aHR 1.80 (95\% CI 1.67-1.94)). Continued current use for $\geqslant 211$ days led to a significantly greater risk of CAP compared with continued current use for <31 days (aHR 2.63 (95\% CI 2.22-3.11) versus 1.90 (95\% CI 1.71-2.12); p<0.001). Furthermore, the risk of CAP remained increased after cessation of H2RA therapy compared with never use.

Our analyses demonstrated no synergistic effect of the combined use of PPIs and H2RAs on the risk of CAP. Concomitant use of PPIs and H2RAs was associated with a 2.5-fold augmented risk of CAP, which did not differ much from the hazard ratios of PPIs and H2RAs separately. When current use of PPIs and/or H2RAs was further stratified by potential confounders, we found that the risk of CAP was even greater in patients with psychomotor disability, a history of pneumonia or asthma (tables 4 and 5).

Discussion

To the best of our knowledge, this is the first large-scale study in the paediatric population assessing the effects of current, past and long-term use of acid suppressants on the risk of developing CAP, and comparing the effects of both PPIs and H2RAs. We found that the use of acid suppressants in children was

TABLE 3 Use of histamine-2 receptor antagonists (H2RAs) and risk of community-acquired pneumonia (CAP)

\begin{tabular}{|c|c|c|c|c|}
\hline Exposure & $\begin{array}{c}\text { CAP } \\
\text { events } n\end{array}$ & $\begin{array}{l}\text { Incidence rate per } \\
1000 \text { person-years }\end{array}$ & $\begin{array}{c}\text { Age/sex-adjusted } \\
\text { HR }(95 \% \mathrm{CI})\end{array}$ & $\begin{array}{l}\text { Fully adjusted } \\
\mathrm{HR}^{\#}(95 \% \mathrm{CI})\end{array}$ \\
\hline Never PPI or H2RA & 21471 & 19.1 & Reference & Reference \\
\hline \multicolumn{5}{|c|}{ H2RA use by time since last prescription } \\
\hline Current: $1-30$ days & 780 & 85.4 & $2.28(2.12-2.45)$ & $1.80(1.67-1.94)$ \\
\hline Recent: $31-60$ days & 491 & 77.3 & $2.04(1.87-2.23)$ & $1.68(1.53-1.85)$ \\
\hline Past: $61-210$ days & 1479 & 66.6 & $1.95(1.85-2.06)$ & $1.65(1.55-1.74)$ \\
\hline Distant past: $\geqslant 211$ days & 3943 & 26.4 & $1.24(1.20-1.29)$ & $1.19(1.15-1.23)$ \\
\hline \multicolumn{5}{|l|}{ Current H2RA use by duration of use } \\
\hline $1-30$ days & 330 & 68.2 & $2.04(1.83-2.27)$ & $1.90(1.71-2.12)$ \\
\hline $31-60$ days & 77 & 87.6 & $1.95(1.56-2.44)$ & $1.83(1.46-2.29)$ \\
\hline $61-210$ days & 237 & 110.8 & $2.45(2.15-2.78)$ & $2.27(1.99-2.58)$ \\
\hline$\geqslant 211$ days & 136 & 106.4 & $3.09(2.61-3.66)$ & $2.63(2.22-3.11)$ \\
\hline Current use of both PPI and H2RA & 73 & 111.1 & $3.47(2.76-4.36)$ & $2.52(2.00-3.18)$ \\
\hline
\end{tabular}

PPI: proton pump inhibitor; HR: hazard ratio. \#: adjusted for age, sex, history of pneumonia, gastro-oesophageal reflux 1 year before, asthma, bronchopulmonary dysplasia and cystic fibrosis. All analyses are adjusted for use of PPIs. 


\begin{tabular}{|c|c|c|c|c|}
\hline Exposure & $\begin{array}{c}\text { CAP } \\
\text { events } n\end{array}$ & $\begin{array}{l}\text { Incidence rate per } \\
1000 \text { person-years }\end{array}$ & $\begin{array}{c}\text { Age/sex-adjusted } \\
\text { HR }(95 \% \mathrm{CI})\end{array}$ & $\begin{array}{c}\text { Fully adjusted } \\
\mathrm{HR}^{\#}(95 \% \mathrm{Cl})\end{array}$ \\
\hline Never PPI or H2RA & 21471 & 19.1 & Reference & Reference \\
\hline $\begin{array}{l}\text { Current PPI use: } \\
1-30 \text { days }\end{array}$ & 739 & 68.4 & $2.66(2.47-2.86)$ & $2.05(1.90-2.22)$ \\
\hline \multicolumn{5}{|l|}{ Per confounder } \\
\hline \multicolumn{5}{|c|}{ History of pneumonia } \\
\hline Yes & 171 & 83.8 & $5.80(4.99-6.75)$ & $3.92(3.37-4.57)$ \\
\hline No & 568 & 64.8 & $2.28(2.09-2.48)$ & $1.86(1.71-2.03)$ \\
\hline \multicolumn{5}{|c|}{$\begin{array}{l}\text { Gastro-oesophageal } \\
\text { reflux }\end{array}$} \\
\hline Yes & 257 & 104.7 & $2.16(1.91-2.44)$ & $2.03(1.79-2.30)$ \\
\hline No & 482 & 57.7 & $3.02(2.76-3.30)$ & $2.41(2.20-2.64)$ \\
\hline \multicolumn{5}{|l|}{ Asthma } \\
\hline Yes & 106 & 56.1 & $4.29(3.54-5.19)$ & $3.13(2.58-3.79)$ \\
\hline No & 633 & 71.0 & $2.50(2.30-2.70)$ & $2.03(1.87-2.21)$ \\
\hline \multicolumn{5}{|c|}{$\begin{array}{l}\text { Bronchopulmonary } \\
\text { dysplasia }\end{array}$} \\
\hline Yes & $<5$ & 189.5 & $3.22(1.04-9.99)$ & $2.47(0.80-7.65)$ \\
\hline No & 736 & 68.2 & $2.66(2.47-2.86)$ & $2.08(1.93-2.25)$ \\
\hline \multicolumn{5}{|l|}{ Cystic fibrosis } \\
\hline Yes & 30 & 65.2 & $2.62(1.83-3.75)$ & $2.17(1.51-3.10)$ \\
\hline No & 709 & 68.5 & $2.66(2.47-2.87)$ & $2.13(1.97-2.30)$ \\
\hline \multicolumn{5}{|c|}{ Psychomotor disability } \\
\hline Yes & 66 & 193.4 & $7.88(6.19-10.04)$ & $6.80(5.34-8.66)$ \\
\hline No & 673 & 64.3 & $2.49(2.31-2.69)$ & $2.02(1.86-2.18)$ \\
\hline
\end{tabular}

associated with a 2-fold increased risk of acquiring CAP. This association was observed for both PPIs and H2RAs, and the increased hazard ratios of the two drug classes were quite similar. With prolonged use, the risk increased over time, especially with continued use for $\geqslant 211$ days. Even after discontinuation of therapy, the risk remained increased for at least 7 months, but decreased over time. Hazard ratios of developing CAP were even greater in acid suppressant users with psychomotor disability, a history of pneumonia or asthma.

There are various explanations for the observed association between the use of acid suppressants and CAP. As an increased risk of CAP in both PPI and H2RA users was found, the observed association may be a consequence of a common denominator of these drugs, such as lowering the $\mathrm{pH}$. Due to our study design, it is not possible to draw definite conclusions about causality but we hypothesise that the reduced $\mathrm{pH}$ leads to a change in the microbiota and to the selection of more pathogenic bacteria in the airways and/or intestines. Consequently, alterations in the airway and/or gut microbiota could increase the risk of CAP.

In vitro studies showed the presence of proton pumps in mucous glands of the human lung [16] and indicated the presence of histamine- 2 receptors in the bronchus [17]. An altered $\mathrm{pH}$ of the mucous secretions in the lungs may alter the respiratory flora and may cause the selection of more pathogenic microorganisms, thereby increasing the risk of CAP [18].

A second hypothesis for the association between acid suppressants and CAP is cross-talk between the intestines and the lung, referred to as the gut-lung axis, suggesting that alterations in the intestinal microbiota can influence the lungs and vice versa [19, 20]. Although our understanding of the gut-lung axis is still at an early stage, it is known that PPIs can induce intestinal dysbiosis [21] and several studies showed that alterations of the gut microbiota can influence the course of respiratory infections. SchUIJ et al. [22] showed that disruption of the gut microbiota impairs immune responses and worsens the course of pneumococcal pneumonia. However, a systematic review and meta-analysis described how the administration of probiotics may positively influence the course and incidence of respiratory infections in 
TABLE 5 Current use of histamine-2 receptor antagonists (H2RAs) and risk of community-acquired pneumonia (CAP) stratified by confounders

\begin{tabular}{|c|c|c|c|c|}
\hline Exposure & $\begin{array}{c}\text { CAP } \\
\text { events } n\end{array}$ & $\begin{array}{l}\text { Incidence rate per } \\
1000 \text { person-years }\end{array}$ & $\begin{array}{c}\text { Age/sex-adjusted } \\
\text { HR }(95 \% \mathrm{CI})\end{array}$ & $\begin{array}{l}\text { Fully adjusted } \\
\mathrm{HR}^{\#}(95 \% \mathrm{CI})\end{array}$ \\
\hline Never PPI and H2RA & 21471 & 19.1 & Reference & Reference \\
\hline $\begin{array}{l}\text { Current H2RA use: } \\
1-30 \text { days }\end{array}$ & 780 & 85.4 & $2.28(2.12-2.45)$ & $1.80(1.67-1.94)$ \\
\hline \multicolumn{5}{|l|}{ Per confounder } \\
\hline \multicolumn{5}{|c|}{ History of pneumonia } \\
\hline Yes & 103 & 104.3 & $5.47(4.51-6.64)$ & $3.91(3.22-4.75)$ \\
\hline No & 677 & 83.1 & $2.09(1.93-2.25)$ & $1.68(1.55-1.82)$ \\
\hline \multicolumn{5}{|l|}{$\begin{array}{l}\text { Gastro-oesophageal } \\
\text { reflux }\end{array}$} \\
\hline Yes & 353 & 107.2 & 2.09 (1.88-2.33) & $2.02(1.81-2.24)$ \\
\hline No & 427 & 73.1 & $2.45(2.23-2.70)$ & $2.17(1.97-2.39)$ \\
\hline \multicolumn{5}{|l|}{ Asthma } \\
\hline Yes & 51 & 58.9 & $3.46(2.63-4.56)$ & $2.62(1.99-3.45)$ \\
\hline No & 729 & 88.2 & $2.22(2.06-2.39)$ & $1.80(1.67-1.95)$ \\
\hline \multicolumn{5}{|l|}{$\begin{array}{l}\text { Bronchopulmonary } \\
\text { dysplasia }\end{array}$} \\
\hline Yes & 6 & 276.3 & $4.86(2.18-10.82)$ & $3.63(1.63-8.06)$ \\
\hline No & 774 & 85.0 & $2.27(2.11-2.44)$ & $1.81(1.67-1.95)$ \\
\hline \multicolumn{5}{|l|}{ Cystic fibrosis } \\
\hline Yes & 12 & 110.9 & $2.68(1.52-4.72)$ & $2.34(1.33-4.13)$ \\
\hline No & 768 & 85.1 & $2.27(2.11-2.44)$ & $1.82(1.68-1.96)$ \\
\hline \multicolumn{5}{|c|}{ Psychomotor disability } \\
\hline Yes & 43 & 270.0 & $8.25(6.11-11.12)$ & $7.02(5.20-9.48)$ \\
\hline No & 737 & 82.1 & $2.19(2.03-2.35)$ & $1.77(1.63-1.91)$ \\
\hline
\end{tabular}

PPI: proton pump inhibitor; HR: hazard ratio. \#: adjusted for age, sex, history of pneumonia, gastro-oesophageal reflux 1 year before, asthma, bronchopulmonary dysplasia and cystic fibrosis; ^: history of gastro-oesophageal reflux 1 year before. All analyses are adjusted for use of PPIs.

children [23]. The effect of intestinal dysbiosis on the lungs could be the consequence of translocation of gastric bacteria into the lungs through (nonacid) gastro-oesophageal reflux with micro-aspiration [24] or result from alterations in the immune response by bacterial products produced in the colon due to the dysbiosis [19, 20].

A third proposed mechanism is that acid suppressants are able to directly alter the function and quantity of cellular components of the immune system, possibly resulting in increased susceptibility to infection. In vitro studies have demonstrated that PPIs inhibit the cytotoxic activity of natural killer cells and impair the function of neutrophils, while famotidine, a H2RA, has been shown to increase the number of inflammatory cells in bronchoalveolar lavage fluid [25-28]. However, with this proposed mechanism, we cannot explain the prolonged increased risk after discontinuation of therapy, as the altered immune response seems to be an on-off phenomenon.

As a fourth hypothesis, it was proposed more recently that the observed association is strongly influenced by confounders such as patients' characteristics, comorbidities or protopathic bias [29, 30]. However, in our analysis, we adjusted for possible confounders such as age, sex, gastro-oesophageal reflux and history of pneumonia, after which the risk of developing CAP remained increased in acid suppressant users. Moreover, we tried to lower the risk of protopathic bias by examining the effects of prolonged use of acid suppressants. With an increased exposure time to acid suppressants, the hazard ratios increased, while the risk gradually decreased after stopping acid suppressant therapy. These findings do not support protopathic bias, although we cannot completely rule out the possibility.

When looking at possible risk modifiers, hazard ratios of developing CAP were even greater in children using acid suppressants with psychomotor disability, a history of pneumonia or asthma. In children with psychomotor disability, the increased risk of CAP may be due to impaired swallowing function, poor oral status and recurrent aspiration [31, 32]. Recurrent CAP may result from various causes such as structural airway anomalies, immunodeficiency, aspiration and asthma [33]. In children with asthma, CAP is also a 
more prevalent condition, possibly as a consequence of poor asthma control resulting in inflammation and intraluminal obstruction [33]. The use of inhaled corticosteroids is also associated with an increased risk of pneumonia [34].

Interestingly, a diagnosis of gastro-oesophageal reflux in current users of our cohort was not associated with an increased risk of developing CAP, which may be explained by two factors. 1) Gastro-oesophageal reflux is often overdiagnosed or misdiagnosed by primary physicians [35]. 2) The increased risk of CAP may not be the direct consequence of aspiration after full-column nonacid reflux, but result from the possible effect of acid suppressants on mucous $\mathrm{pH}$ and the gut/lung microbiota.

Our data add to the growing evidence that the use of acid suppressants is associated with the development of CAP. In the literature on adult patients, multiple papers have reported on this association. In a large systematic review and meta-analysis including 6351656 participants, LAMBERT et al. [9] observed a 1.5-fold increased risk of developing CAP in patients using PPIs. A second meta-analysis, performed by JoHNSTONE et al. [7] in around 1 million patients, demonstrated similar results, with a 1.4-fold increased risk of CAP with PPI use. Eom et al. [8] also found a significant association between PPIs and CAP, with a 1.3-fold increased risk, and a 1.2-fold increased risk of hospital-acquired pneumonia in H2RA users. In our study with children, we found even greater risk ratios for the association between acid suppressants and CAP than in these studies in adults.

So far, only two paediatric studies have been performed specifically targeting this association, showing conflicting results. CANANI et al. [10] found a negative association between acid suppressants and CAP in a small group of 186 children aged 4-36 months who were prescribed a PPI or H2RA for 2 months. At 4-month follow-up, they found a 6-fold increased risk of developing CAP with either PPI or H2RA use. BLANK et al. [11] performed a nested case-control study in 21911 infants, demonstrating that current use of PPIs in infants does not increase the risk of CAP compared with past use. It is likely that they did not observe an increased hazard when comparing current use to past use, as in our study past use was still associated with an increased risk of acquiring CAP. In addition, their primary outcome was CAP or lower respiratory tract infection leading to hospitalisation or death, which clearly differs from the definition of CAP in the general population in our study.

Our study has several strengths. The main strength is that this is the first large study in children to examine this association, in which the effects of prolonged use and cessation of therapy were also assessed. In addition, we studied the role of both PPI and H2RA use, and were able to compare the hazard ratios on CAP related to these two drugs. Our results are likely to be generalisable as the CPRD database population has been shown to be representative for the UK population, as well as populations outside the UK $[13,14]$.

Our study also has several limitations. Due to its observational nature, the results may be biased by exposure and/or outcome misclassification. Also, residual confounding cannot be completely excluded as it is possible that possible confounders were underreported. Due the study design we cannot establish a causal relationship between the use of acid suppressants and CAP. Moreover, we were not able to discriminate between a viral or bacterial origin of CAP in our study due to the study design.

In conclusion, this study showed that the use of acid suppressants in children, both PPIs and H2RAs, is associated with an average 2-fold increased risk of acquiring CAP. The risk of CAP further increased over time with continued use for $\geqslant 211$ days. After cessation of therapy, the risk remained increased for at least 7 months. Patients with psychomotor disability, a history of pneumonia or asthma using an acid suppressant had an even greater risk of CAP.

Author contributions: L.J.T.M. van der Sande, Q. Jöbsis, F. de Vries, E. Dompeling, E.M.W. van de Garde, J.J.M. Coremans and J.H.M. Driessen designed the study. J.H.M. Driessen, F. de Vries and L.J.T.M. van der Sande were responsible for the data extraction. L.J.T.M. van der Sande, Q. Jöbsis, M.A.G.E. Bannier, F. de Vries, E. Dompeling and J.H.M. Driessen wrote the paper. L.J.T.M. van der Sande and Q. Jöbsis performed a systematic review of the literature on this subject. All authors critically revised the article and approved the final version.

The protocol for this study was approved by the Independent Scientific Advisory Committee (ISAC) for Medicines and Healthcare products Regulatory Agency (MHRA) Database research (protocol 18_107). Clinical Practice Research Datalink (CPRD) GOLD data for this study have been sublicensed from the MHRA by Utrecht University and are subject to an agreement that does not allow further sharing with others. However, CPRD GOLD data, 
either for original or replication studies, are available from the licensor to any team of researchers who meet appropriate qualifications, subject to a priori scientific approval of the study protocol by the ISAC and the availability of a sublicensing agreement. Data dictionaries of exposures and outcomes are available for auditing purposes.

Conflict of interest: L.J.T.M. van der Sande has nothing to disclose. Q. Jöbsis has nothing to disclose. M.A.G.E. Bannier has nothing to disclose. E.M.W. van de Garde has nothing to disclose. J.J.M. Coremans has nothing to disclose. F. de Vries is supervisor to two PhD students who are employed by F. Hoffmann La Roche Ltd (Basel, Switzerland and Welwyn Garden City, UK); the topics of the studies are not related to the current manuscript and no fees or reimbursements have been received for this. E. Dompeling has nothing to disclose. J.H.M. Driessen has nothing to disclose.

\section{References}

1 Barron JJ, Tan H, Spalding J, et al. Proton pump inhibitor utilisation patterns in infants. J Pediatr Gastroenterol Nutr 2007; 45: 421-427.

2 De Bruyne P, Christiaens T, Vander Stichele R, et al. Changes in prescription patterns of acid-suppressant medications by Belgian pediatricians: analysis of the national database, 1997-2009. J Pediatr Gastroenterol Nutr 2014; 58: 220-225.

3 Blank ML, Parkin L. National study of off-label proton pump inhibitor use among New Zealand infants in the first year of life (2005-2012). J Pediatr Gastroenterol Nutr 2017; 65: 179-184.

4 Aznar-Lou I, Reilev M, Lodrup AB, et al. Use of proton pump inhibitors among Danish children: a 16-year register-based nationwide study. Basic Clin Pharmacol Toxicol 2018; 124: 704-710.

5 Rosen $\mathrm{R}$, Vandenplas $\mathrm{Y}$, Singendonk $\mathrm{M}$, et al. Pediatric gastroesophageal reflux clinical practice guidelines: joint recommendations of the North American Society for Pediatric Gastroenterology, Hepatology, and Nutrition and the European Society for Pediatric Gastroenterology, Hepatology, and Nutrition. J Pediatr Gastroenterol Nutr 2018; 66: 516-554.

6 Laheij RJ, Sturkenboom MC, Hassing RJ, et al. Risk of community-acquired pneumonia and use of gastric acid-suppressive drugs. JAMA 2004; 292: 1955-1960.

7 Johnstone J, Nerenberg K, Loeb M. Meta-analysis: proton pump inhibitor use and the risk of community-acquired pneumonia. Aliment Pharmacol Ther 2010; 31: 1165-1177.

8 Eom CS, Jeon CY, Lim JW, et al. Use of acid-suppressive drugs and risk of pneumonia: a systematic review and meta-analysis. CMAJ 2011; 183: 310-319.

9 Lambert AA, Lam JO, Paik JJ, et al. Risk of community-acquired pneumonia with outpatient proton-pump inhibitor therapy: a systematic review and meta-analysis. PLoS One 2015; 10: e0128004.

10 Canani RB, Cirillo P, Roggero P, et al. Therapy with gastric acidity inhibitors increases the risk of acute gastroenteritis and community-acquired pneumonia in children. Pediatrics 2006; 117: e817-e820.

11 Blank ML, Parkin L, Zeng J, et al. Proton pump inhibitors and infant pneumonia/other lower respiratory tract infections: national nested case-control study. J Pediatr Gastroenterol Nutr 2018; 67: 335-340.

12 Global Burden of Disease Pediatrics Collaboration. Global and national burden of diseases and injuries among children and adolescents between 1990 and 2013: findings from the Global Burden of Disease 2013 study. JAMA Pediatr 2016; 170: 267-287.

13 Herrett E, Gallagher AM, Bhaskaran K, et al. Data resource profile: Clinical Practice Research Datalink (CPRD). Int J Epidemiol 2015; 44: 827-836.

14 de Jong RG, Gallagher AM, Herrett E, et al. Comparability of the age and sex distribution of the UK Clinical Practice Research Datalink and the total Dutch population. Pharmacoepidemiol Drug Saf 2016; 25: 1460-1464.

15 Harris M, Clark J, Coote N, et al. British Thoracic Society guidelines for the management of community acquired pneumonia in children: update 2011. Thorax 2011; 66: Suppl. 2, ii1-ii23.

16 Altman KW, Waltonen JD, Tarjan G, et al. Human lung mucous glands manifest evidence of the $\mathrm{H}^{+} / \mathrm{K}^{+}$-ATPase proton pump. Ann Otol Rhinol Laryngol 2007; 116: 229-234.

17 Dunlop LS, Smith AP, Piper PJ. The effect of histamine antagonists on antigen-induced contractions of sensitised human bronchus in vitro. Br J Pharmacol 1977; 59: 475P.

18 Fohl AL, Regal RE. Proton pump inhibitor-associated pneumonia: not a breath of fresh air after all? World $J$ Gastrointest Pharmacol Ther 2011; 2: 17-26.

19 Budden KF, Gellatly SL, Wood DL, et al. Emerging pathogenic links between microbiota and the gut-lung axis. Nat Rev Microbiol 2017; 15: 55-63.

20 Marsland BJ, Trompette A, Gollwitzer ES. The gut-lung axis in respiratory disease. Ann Am Thorac Soc 2015; 12: Suppl. 2, S150-S156.

21 Naito Y, Kashiwagi K, Takagi T, et al. Intestinal dysbiosis secondary to proton-pump inhibitor use. Digestion 2018; 97: 195-204.

22 Schuijt TJ, Lankelma JM, Scicluna BP, et al. The gut microbiota plays a protective role in the host defence against pneumococcal pneumonia. Gut 2016; 65: 575-583. 
23 Wang Y, Li X, Ge T, et al. Probiotics for prevention and treatment of respiratory tract infections in children: a systematic review and meta-analysis of randomised controlled trials. Medicine 2016; 95: e4509.

24 Rosen R, Amirault J, Liu $\mathrm{H}$, et al. Changes in gastric and lung microflora with acid suppression: acid suppression and bacterial growth. JAMA Pediatr 2014; 168: 932-937.

25 Mikawa K, Akamatsu $\mathrm{H}$, Nishina $\mathrm{K}$, et al. The effects of cimetidine, ranitidine, and famotidine on human neutrophil functions. Anesth Analg 1999; 89: 218-224.

26 Aybay C, Imir T, Okur H. The effect of omeprazole on human natural killer cell activity. Gen Pharmacol 1995; 26: $1413-1418$.

27 Zedtwitz-Liebenstein K, Wenisch C, Patruta S, et al. Omeprazole treatment diminishes intra- and extracellular neutrophil reactive oxygen production and bactericidal activity. Crit Care Med 2002; 30: 1118-1122.

28 Ferstl R, Frei R, Barcik W, et al. Histamine receptor 2 modifies iNKT cell activity within the inflamed lung. Allergy 2017; 72: 1925-1935.

29 Othman F, Crooks CJ, Card TR. Community acquired pneumonia incidence before and after proton pump inhibitor prescription: population based study. BMJ 2016; 355: i5813.

30 Filion KB. Proton pump inhibitors and community acquired pneumonia. BMJ 2016: 355: 16041.

31 Kaymaz N, Ozcelik U, Demir N, et al. Swallowing dysfunction as a factor that should be remembered in recurrent pneumonia: videofluoroscopic swallow study. Minerva Pediatr 2017; 69: 396-402.

32 Millman AJ, Finelli L, Bramley AM, et al. Community-acquired pneumonia hospitalisation among children with neurologic disorders. J Pediatr 2016; 173: 188-195.

33 Panitch HB. Evaluation of recurrent pneumonia. Pediatr Infect Dis J 2005; 24: 265-266.

34 Qian CJ, Coulombe J, Suissa S, et al. Pneumonia risk in asthma patients using inhaled corticosteroids: a quasi-cohort study. Br J Clin Pharmacol 2017; 83: 2077-2086.

35 Quitadamo P, Papadopoulou A, Wenzl T, et al. European pediatricians' approach to children with GER symptoms: survey of the implementation of 2009 NASPGHAN-ESPGHAN guidelines. J Pediatr Gastroenterol Nutr 2014; 58: 505-509. 